\title{
PENERAPAN HYGIENE DAN SANITASI DI PONDOK PESANTREN AS'AD SEBERANG KOTA JAMBI TAHUN 2016
}

\author{
Supriadi ${ }^{1}$, Emilia Chandra
}

\begin{abstract}
Various diseases based environment that is often a problem in General "as scabies, diarrhea, RESPIRATORY, caused by a less healthy environments in boarding schools ("). This research aims to gain an overview of the application of the Hygiene Sanitary boarding schools Usa, ad in the town of Jambi. The method of this research uses descriptive design answered the question question about who, what, when, where and how the interconnectedness with particular research. Data analysis analyzes the data Union variat and presented in tabular form then analyzed are descriptive. This research makes a picture about the State of Hygiene and sanitation of U.s. boarding schools, ad opposite the city of Jambi. The research results obtained that the application of Hygiene and sanitation in the US boarding schools, ad is still low and the students Knowledge about Hygiene and sanitation at boarding schools. It is suggested the necessity of understanding the material about basic sanitation to students and Personnel needed to improve sanitation sanitation conditions in boarding schools across the city of Jambi As'ad
\end{abstract}

Key words: boarding schools, Hygiene and sanitation

\section{PENDAHULUAN}

Sanitasi atau kesehatan lingkungan sangatlah penting untuk tetap menjaga kesehatan suatu lingkungan dalam upaya mencegah terjadinya masalah gangguan kesehatan akibat faktor lingkungan yang dapat berpotensi merugikan kesehatan. Usaha-usaha yang dilakukan oleh individu-individu, masyarakat, atau negara untuk memperbaiki dan mencegah terjadinya masalah gangguan kesehatan yang disebabkan oleh faktor-faktor lingkungan hidup eksternal manusia disebut sanitasi lingkungan atau environmental Sanitation (Chandra, Budiman, 2007:1-2).

Dalam pelayanan segala kebutuhan yang diperlukan telah siap sedia, seperti pelayanan akomodasi, restoran, bar, fitness center, transportasi, dsb. Semua fasilitas ini tidak hanya menampilkan mutu, citarasa masakan, kenyamanan

1 Poltekes Kemenkes Jambi Jurusan Kesehatan Lingkungan saja, akan tetapi faktor yang sangat penting adalah menyangkut kenyamanan dan kepastian atau jaminan kebersihan untuk kesehatan sesuai tujuan orang menikmati fasilitas tersebut demi kelangsungan hidupnya yaitu "hygiene dan Sanitasi" (kesehatan dan kebersihan). Untuk itu dalam mengelola seluruh fasilitas yang ditawarkan secara professional haruslah sesuai dengan aturan kesehatan yang berlaku, sehingga pengguna jasa mendapatkan kenikmatannya sendiri dengan jaminan kesehatan.

Pada akhirnya terjadilah dalam usaha bisnis hotel, restoran dan catering persaingan dalam kualitas atau mutu pelayanan yang mencakup kebersihan sebagai jaminan kesehatan. Pondok pesantren merupakan suatu tempat dengan jumlah penghuni yang cukup banyak, sehingga kebutuhan air secara kualitas dan kuantitas sangat diperlukan sebagai penunjang sanitasi lingkungan dan higiene perorangan penghuninya. 
Dilihat dari sisi kesehatan, pada umumnya pondok pesantren tradisional masih memerlukan perhatian dari berbagai pihak yang terkait, baik dalam aspek akses pelayanan kesehatan, perilaku sehat maupun aspek kesehatan lingkungannya. Pondok pesantren dinilai masih kurang memperhatikan kesehatan santri dan lingkungannya. Pondok Pesantren beresiko menimbulkan gangguan kesehatan sebesar 40\% - 95\% (Kemenkes RI, 2014). Penyakit menular yang berbasis lingkungan dan perilaku seperti Tuberkulosis (TBC), Infeksi Saluran Pernapasan Atas (ISPA), diare dan penyakit kulit masih merupakan masalah kesehatan masyarakat yang dominan di pondok pesantren tradisional

Pondok pesantren, selain dikenal sebagai wahana tempat belajar santri dan santriwati dalam mendalami ilmu agama Islam, namun ponpes selama ini juga dikenal bermasalah dari aspek sanitasi. Berbagai penyakit berbasis lingkungan yang umum sering menjadi masalah di Ponpes seperti kudis, diare, ISPA, disebabkan oleh lingkungan yang kurang sehat di Pondok Pesantren (Ponpes).

Tabel 1

Daftar Pondok Pesantren di Kota Jambi

\begin{tabular}{lllc}
\hline No & Ponpes & Lokasi (Kec.) & Jumlah Siswa \\
\hline 1. & Nurul Iman & Pelayangan & 267 \\
2. & Sa'adatuddaren & Pelayangan & 707 \\
3. & Al Jauharen & Pelayangan & 349 \\
4. & As'ad & Danau Teluk & 2.056 \\
5. & PPM Al Hidayah & Kota Baru & 1.062 \\
6. & Ma'had A-Mubarok & Pelayangan & 887 \\
7. & Darul Muhtadin & Pelayangan & 180 \\
8. & TQ. Arriyad & Pelayangan & 157 \\
9. & Mambaul Ulum & Jambi Selatan & 771 \\
10. & Ainul Yaqin & Jelutung & 193 \\
11. & Tahfidz Darul Hikmah & Jambi Selatan & 35 \\
12. & PP Ubay Bin Ka'ab & Telanaipura & 55 \\
13. & PP Darussalam Al Hafidz & KotaBaru & 73 \\
& Jumlah & & 6.792 \\
\hline
\end{tabular}

Siswa pondok pesantren di Kota dari 3.619 siswa laki-laki dan 3.173 Jambi sebanyak 6.792 orang yang terdiri perempuan. Dengan jumlah guru 
sebanyak 499 orang yang terdiri dari 313 laki-laki dan 186 orang perempuan. Pondok Pesantren tersebut tersebar di Kota Jambi dan Seberang Kota Jambi, Pondok Pesantren terbanyak terdapat di Kecamatan Pelayangan yaitu sebanyak 6 Pondok Pesantren Pondok pesantren dengan siswa terbanyak terdapat di Pesantren As'ad di Kecamatan Danau Teluk sebanyak 2.056 orang dan siswa yang paling sedikit di Pondok Pesantren Tahfidz Darul Hikmah sebanyak 35 orang,

Berdasarkan hasil observasi awal yang dilakukan pada pondok pesantren As,as Seberang kota Jambi didapatkan gambaran antara lain banyak ditemukan Sanitasi Ponpes yang kurang memadai, higiene perorangan pada santri yang buruk, pengetahuan, sikap, dan perilaku para santri yang kurang mendukung pola hidup sehat, serta pihak penghelola ponpes yang kurangnya pengetahuan tentang Hygiene Sanitasi, sehingga banyak ditemukan penyakit berbasis Lingkungan.

Beberapa komponen yang diamati adalah sanitasi lingkungan Ponpes yang terdiri dari lokasi dan konstruksi Ponpes, penyediaan air bersih, ketersediaan jamban, pengelolaan sampah, sistem pembuangan air limbah, sanitasi dan kepadatan pemondokan, sanitasi ruang belajar santri, dan sanitasi masjid Ponpes.

Berdasarkan fenomena tersebut peneliti merumuskan masalah bahwa Dari hasil survey awal di pondok pesantren As,ad di Kota Jambi terdapat beberapa penghuni menderita penyakit berbasis lingkungan seperti penyakit kulit dan kutu rambut dan kondisi lingkungan belum memenuhi syarat kesehatan

Adapun tujuan dari penelitian ini adalah: 1) Mendapatkan gambaran penerapan Hygiene Sanitasi Pondok Pesantren As,ad di Kota Jambi; 2) Mengetahui gambaran penerapan
Hygiene Sanitasi Pondok Pesantren As,ad di Kota Jambi; 3) Mengetahui tingkat pengetahuan para santri di Pondok pesantren di Kota Jambi tentang Hygiene Sanitasi

\section{METODE PENELITIAN}

\section{Tahapan-tahapan penelitian}

1. Tahap persiapan.

a. Mengurus izin penelitian dan Mengumpulkan data sekunder

b. Observasi awal pada pesantren As,ad kota Jambi

c. Mempersiapkan alat untuk pengambilan data

d. Menentukan permasalahan

e. Tindak lanjut

2. Tahap Pelaksanaan

a. Mengamati Penyediaan air bersih/ air minum (water supply) Meliputi Pengawasan terhadap kualitas dan kuantitas, Pemanfaatan air, Penyakit-penyakit yang ditularkan melalui air, Cara pengolahan, Cara pemeliharaan.

b. Mengamati pengolahan sampah (refuse disposal) Meliputi Cara/system pembuangan Peralatan pembuangan dan cara penggunaannya serta cara pemeliharaannya

c. Mengamati pengolahan makanan dan minuman (food sanitation) pengadaan bahan makanan/bahan baku, Penyimpanan bahan makanan/bahan baku, Pengolahan makanan, Pengangkutan makanan, Penyimpanan makanan, Penyajian makanan

d. Mengamati pengawasan/pengendalian serangga dan binatang pengerat (insect and rodent control)Meliputi cara pengendalian vector

\section{Rancangan Penelitian}


Penelitian ini membuat gambaran tentang keadaan Hygiene dan sanitasi Pondok Pesantren As,ad Seberang Kota Jambi

\section{Desain Penelitian}

Penelitian ini menggunakan desain deskriptif menjawab atas pertanyaan pertanyaan tentang siapa, apa, kapan, di mana dan bagaimana keterkaitan dengan penelitian tertentu. Penelitian deskriptif digunakan untuk memperoleh informasi mengenai status fenomena variabel atau kondisi situasi, dalam penelitian ini membuat gambaran tentang keadaan Hygiene dan Sanitasi Pondok Pesantren As, ad secara objektif.

\section{Metode yang digunakan}

Metode penelitian yang digunakan dalam penelitian ini meliputi beberapa tahap yaitu pengumpulan data, kemudian di olah secara manual dengan tahaptahap editing, tabulasi, dan kemudian dilakukan analisis secara deskriptif dengan membandingkan dengan peraturan yang ada

\section{Perubahan yang di amati/diukur}

Mengamati objek penelitian yaitu persyaratan kesehatan lingkungan Serta tindakan santri dalam menjaga dan memelihara sanitasi Pondok Pesantren

\section{Lokasi penelitian}

Tempat penelitian dilakukan di Pondok pesantren As,ad di Kota Jambi, dan dilakukan bulan April sampai dengan September 2016

\section{Populasi dan Sampel}

1. Populasi

Populasi dalam peneliti adalah semua Pengelola dan Santri yang ada di Pondok Pesantren AS'ad Seberang Kota Jambi

2. Sampel
Menurut Sugiyono (2008:116) "sampel adalah sebagian dari jumlah dan karakteristik yang dimiliki oleh populasi tersebut". Sedangkan menurut Arikunto (2008:116) "Penentuan pengambilan Sample sebagai berikut : Apabila kurang dari 100 lebih baik diambil semua hingga penelitiannya merupakan penelitian populasi. Jika jumlah subjeknya besar dapat diambil antara $10-15 \%$ atau $20-55 \%$ atau lebih tergantung sedikit banyaknya dari:

a. Kemampuan peneliti dilihat dari waktu, tenaga dan dana

b. Sempit luasnya wilayah pengamatan dari setiap subyek, karena hal ini menyangkut banyak sedikitnya dana.

c. Besar kecilnya resiko yang ditanggung oleh peneliti untuk peneliti yang resikonya besar, tentu saja jika samplenya besar hasilnya akan lebih baik

Dalam Penelitian ini sampel yang diambil sebanyak $10 \%$ dari populasi yaitu $10 \%$ x $833=83$ sampel

\section{Teknik Penarikan Sampel}

Penarikan sampel dengan cara Proportional sampling dengan cara memperhatikan pertimbangan unsurunsur atau kategori dalam populasi penelitian

\section{Teknik Pengumpulan data}

Pengumpulan data dilaksanakan dengan beberapa tahap yaitu ;

1. Melakukan wawancara dengan menggunakan kuesioner

2. Melakukan observasi dengan menggunakan ceklist

\section{Analisis Data}

Menganalisa data secara uni variat dan disajikan dalam bentuk tabel kemudian dianalisis secara deskriptif 


\section{HASIL DAN PEMBAHASAN \\ Gambaran umum}

Yayasan perguruan As'ad di pimpin oleh Kiyai Haji M. Nadjmi, terdiri dari Madrasah Aliya dan Madrasah Tsanawiyah, MTs. Putra As'ad merupakan salah satu pesantren yang terdapat di JL. Kyai Haji Abdul Qodir Ibrahim, No. 45 Olak kemang Kec. danau teluk kota Jambi dengan jumlah

Tabel 2 santri sebanyak 833 orang denga rincian santri putri sebanyak 423 orang, sedangkan jumlah santri putra sebanyak 410 orang dengan jumlah staf dan pengajar sebanyak 62 orang.

Setelah dilaksanakan pengambilan data ditemukan masalah kesehatan yang ada di pondok pesantren As'ad Seberang Kota Jambi sebagai berikut :

Permasalahan kesehatan pada Pondok Pesantren As'ad

\begin{tabular}{|c|c|c|c|}
\hline No & Masalah Kesling & Masalah PHBS & Masalah Sarana \\
\hline 1 & $\begin{array}{l}\text { Sampah yang berserakan di } \\
\text { lingkungan pesantren }\end{array}$ & $\begin{array}{l}\text { Sisa dan bungkus } \\
\text { makanan berserakan di } \\
\text { asrama dan halaman }\end{array}$ & $\begin{array}{l}\text { Tempat lemari } \text { yang } \\
\text { sempit sehingga } \\
\text { dibersihkan }\end{array}$ \\
\hline 2 & Kasur tidak dijemur & $\begin{array}{l}\text { Sisa makanan tidak } \\
\text { dibersihkan }\end{array}$ & $\begin{array}{l}\text { Ruang Asrama tidak } \\
\text { sesuai dengan jumlah } \\
\text { penghuni }\end{array}$ \\
\hline 3 & Lantai Asrama jarang di pel & $\begin{array}{l}\text { Pakaian yang sudah } \\
\text { digunakan bergantungan } \\
\text { didalam asrama }\end{array}$ & $\begin{array}{l}\text { Lantai terbuat dari } \\
\text { papan }\end{array}$ \\
\hline 4 & $\begin{array}{l}\text { Air limbah tidak mengalir } \\
\text { lancar kedalam got sehingga } \\
\text { menjadi sarang nyamuk }\end{array}$ & $\begin{array}{l}\text { Kain basahan mandi } \\
\text { digunakan bergantian }\end{array}$ & Saluran got tidak layak \\
\hline 5 & $\begin{array}{l}\text { Dilapangan pesantren } \\
\text { berdebu dan banyak sampah }\end{array}$ & $\begin{array}{l}\text { Membuang } \\
\text { sembarangan }\end{array}$ & $\begin{array}{l}\text { Tempat sampah kecil, } \\
\text { tidak memiliki tutup } \\
\text { dan berserakan }\end{array}$ \\
\hline 6 & Bak mandi jarang di kuras & $\begin{array}{l}\text { Ember sabun, sepatu dan } \\
\text { sandal diletakan } \\
\text { sembarangan di dalam } \\
\text { asrama }\end{array}$ & $\begin{array}{l}\text { Saluran SPAL } \\
\text { lancar }\end{array}$ \\
\hline 7 & Kamar mandi jarang di kuras & $\begin{array}{l}\text { Bantal sering dipakai } \\
\text { bersama sama }\end{array}$ & Lantai licin \\
\hline 8 & $\begin{array}{l}\text { Saluran air mandi tersumbat } \\
\text { oleh sampah }\end{array}$ & $\begin{array}{l}\text { Tidur tidak menggunakan } \\
\text { kelambu }\end{array}$ & $\begin{array}{l}\text { Kurangnya tempat } \\
\text { menjemur pakaian }\end{array}$ \\
\hline
\end{tabular}

\section{Umum}

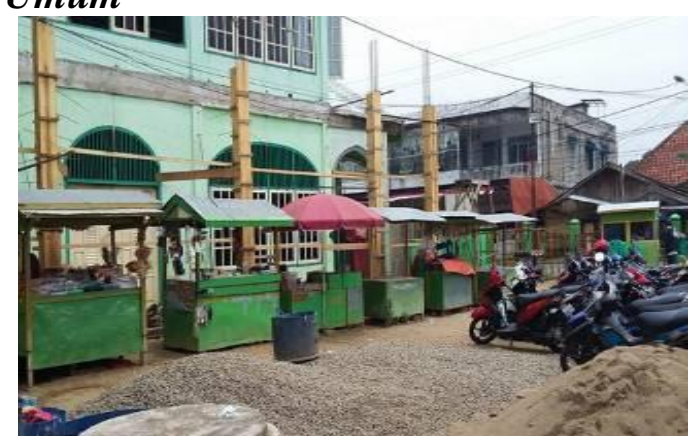

Halaman sekolah berdebu, tidak rapi, dan bila hujan terdapat genangan air, banyak sampah yang berserakan. Bangunan Pondok pesantren bagian depan terlihat kuat, kokoh, terpelihara dan bersih berbeda dengan bagian dalam bangunan. 


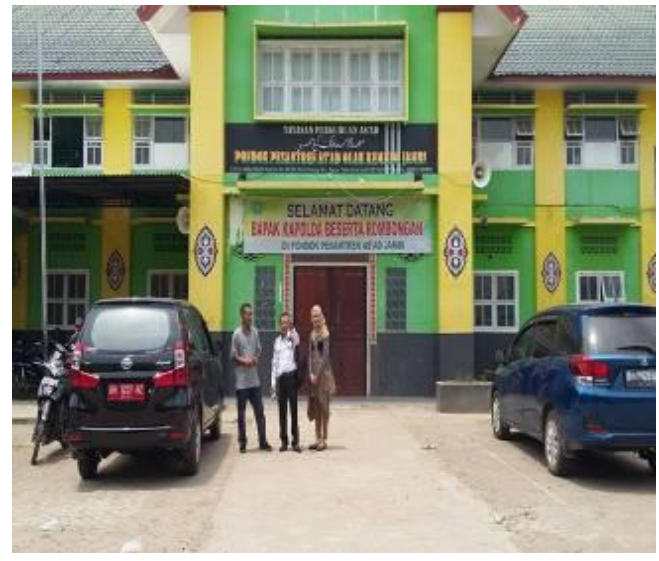

\section{Konstruksi}

Ruangan asrama terdiri dari aula yang digunakan untuk berkumpul dan sholat, Kamar digunakan untuk tidur dan meletakan semua per alatan, baju dan lainnya. kamar terdiri dari 19 kamar untuk putra dan 19 kamar untuk putri, kamar berukuran 6 x 4 m dengan penghuni sebanyak 15 orang. Pada kamar, langit-langit, dinding dan lantai bersih, dinding dari pasangan bata yang diplester dan di cat rapi serta kedap air, lantai papan dialas tikar plastik, lemari pakaian dibuat seragam dan disusun disetiap sisi dinding asrama, kasur pada saat tidak digunakan ditumpuk disudut ruangan, baju dan peralatan sholat digantung di tengah-tengah ruangan. Tidak terdapat jendela hanya beberapa ventilasi kurang dari 10\%, pencahayaan dibantu lampu, cukup terang dan tidak silau

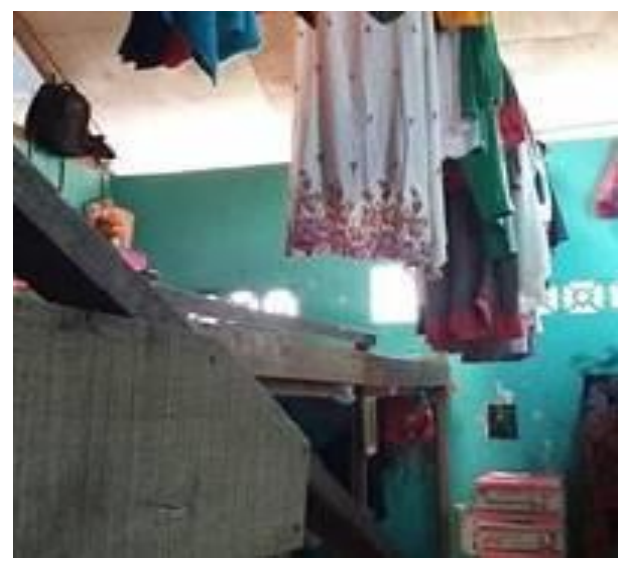

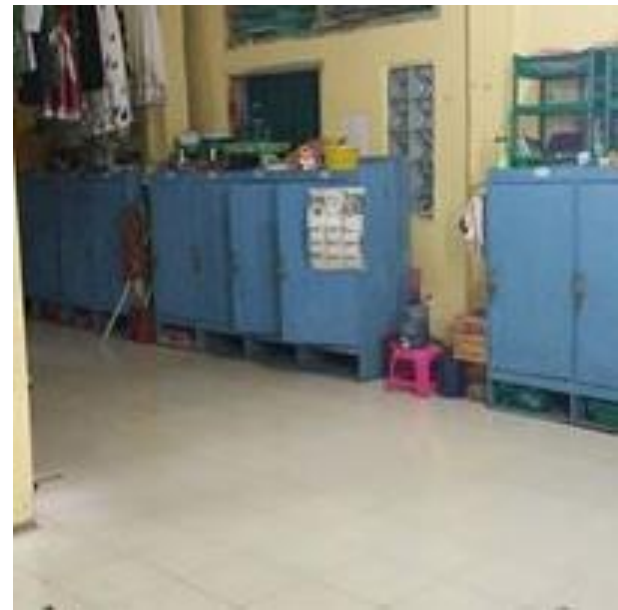
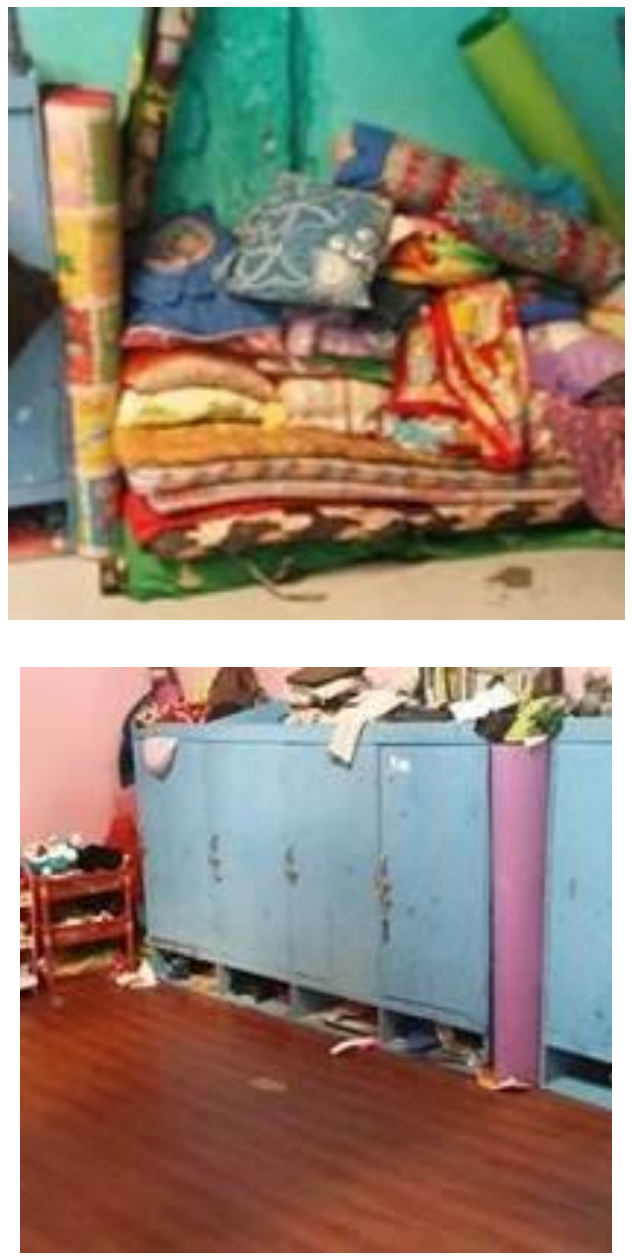

Atap memiliki kemiringan cukup dan tidak ada genangan air, baik air kotor maupun air bersih, dinding bersih dan kuat, tidak retak dan tidak pecah, permukaan bagian dalam dicat rapi dan mudah dibersihkan. Lantai terbuat dari 
papan yang kuat dan bersih dan tidak licin.
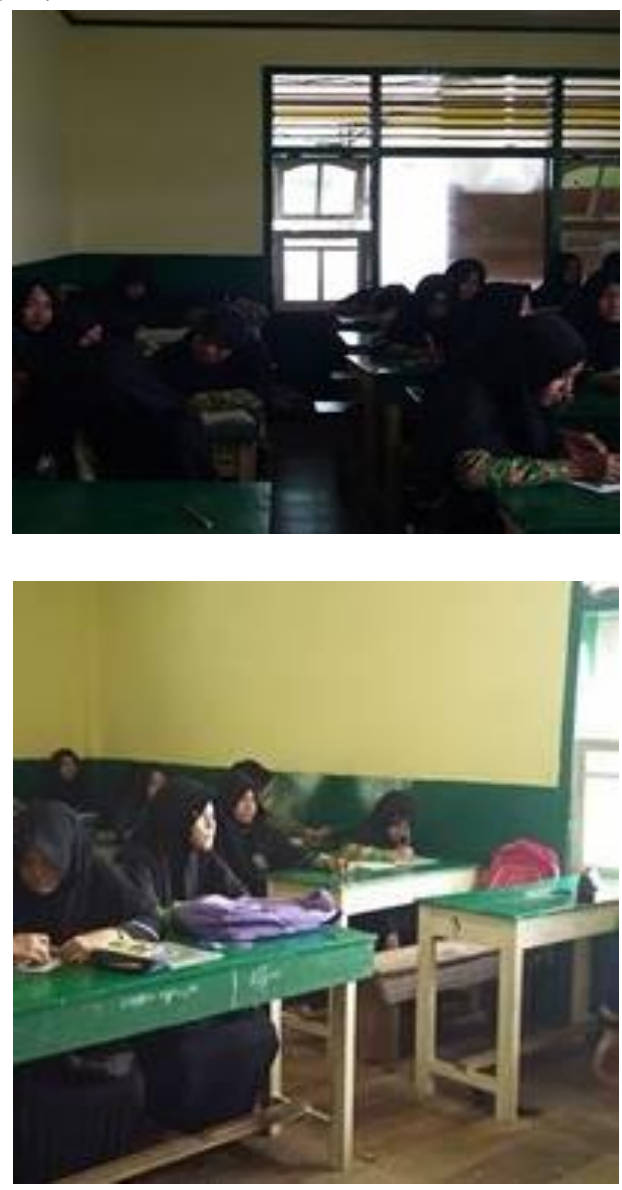

Tangga pada kelas di pondok pesantren As'ad terdapat dua jenis yang permanen dan non permanen, lebar injakan tangga permanen $\geq 30 \mathrm{~cm}$, tinggi anak $\leq 20 \mathrm{~cm}$, lebar tangga $\geq 150 \mathrm{~cm}$, namun tidak terdapat pegangan tanggan.

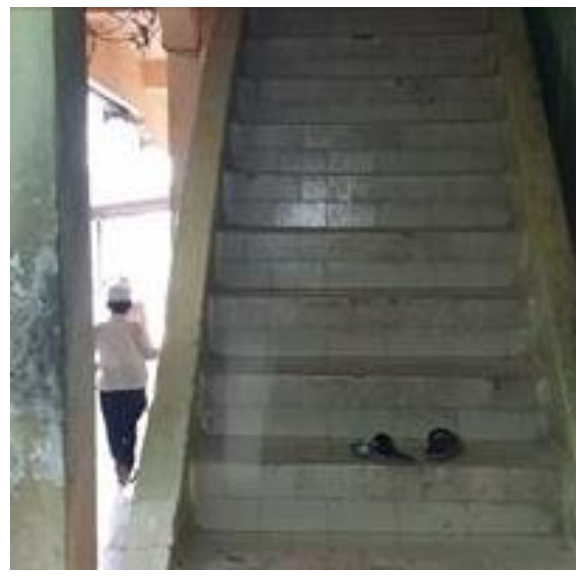

Untuk tangga non permanen lebar injakan tangga permanen $\leq 30 \mathrm{~cm}$, tinggi anak $\geq 20 \mathrm{~cm}$, lebar tangga $\leq 150 \mathrm{~cm}$, namun terdapat pegangan tanggan.

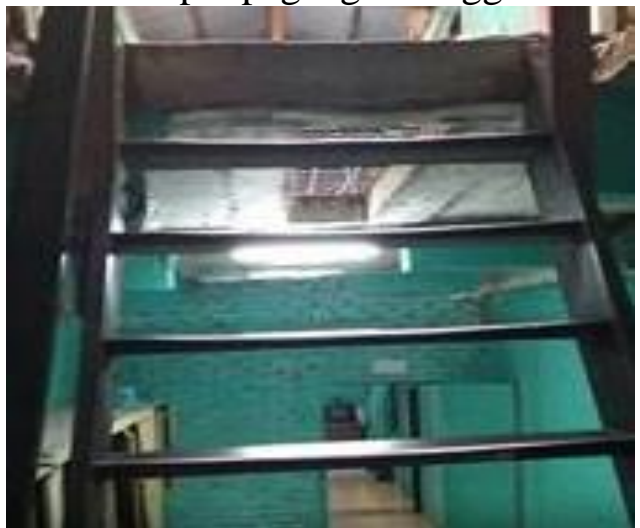

Pencahayaan ruang kelas cukup, dapat untuk membaca buku dengan jelas tanpa bantun penerangan pada siang hari demikian juga ruang perpustakkan dan ruang labor. Ventilasi pada kelas cukup memenuhi persyaratan kesehatan, 80\% ruang kelas yang tidak menggunakan AC luas ventilsi ruang kelas $\geq 20 \%$ Kelas tidak terlalu padat, setiap santri mendapat ruang lebih dari $1,75 \mathrm{~m} 2$, Jarak papan tulis dengan santri yang duduk di depan lebih dari 2,5 m, dan dari santri yang duduk dibelakang kurang dari $9 \mathrm{~m}$. Tidak terdapat tempat cuci tangan pada ponpes ini, namun terdapat tempat berwudhu

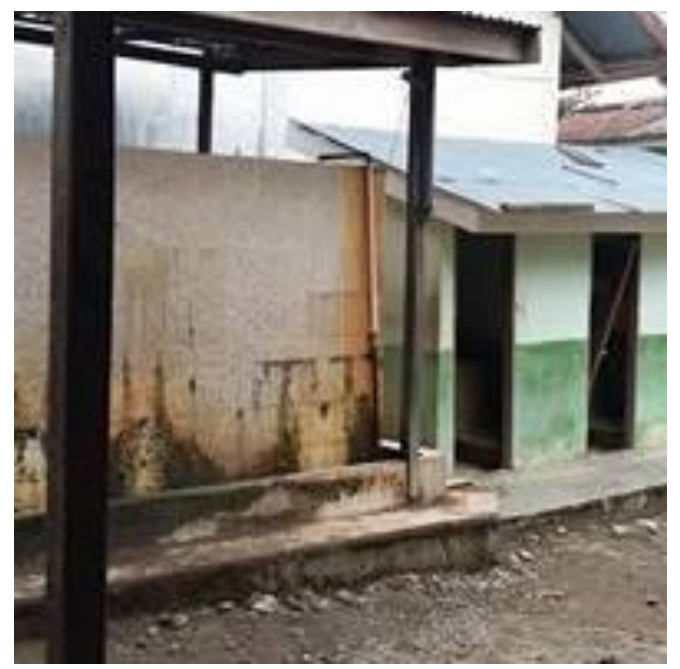


suasana kelas cukup bising karena kelas berada di lingkungan aula sehingga santri yang sedang belajar terganggu oleh kegiatan santri lainnya di aula. Meja belajar tidak miring, rata dan kurang kokoh
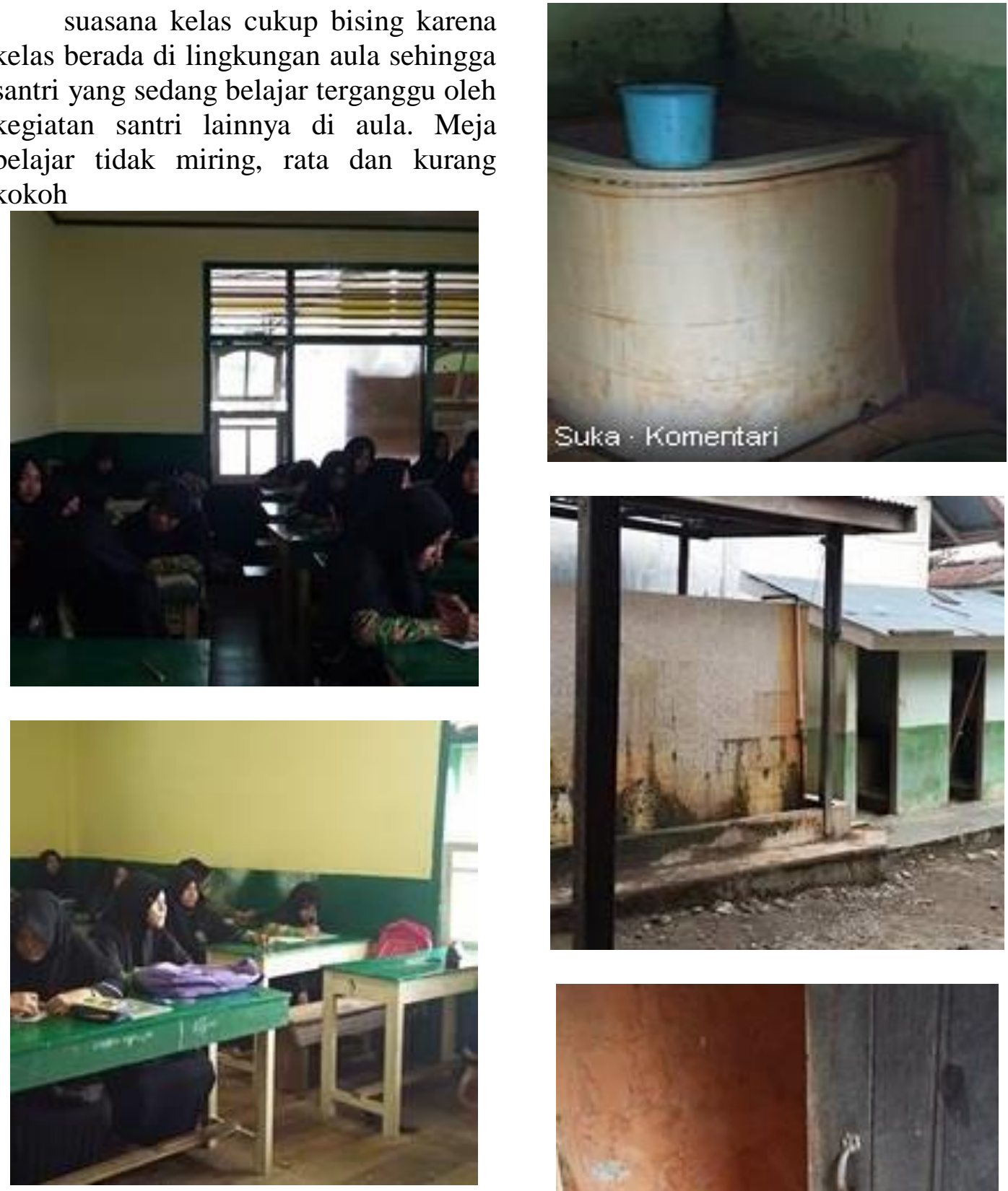

\section{Sarana Sanitasi}

Sarana air bersih menggunakan sumur bor, dengan kondisi fisik air berwarna kecokalatan dan tidak layak untuk air minum, Jamban leher angsa dan berada dalam ruangan tertutup namun dalam keadaan kotor dan tidak pernah dibersihkan, Air limbah langsung di

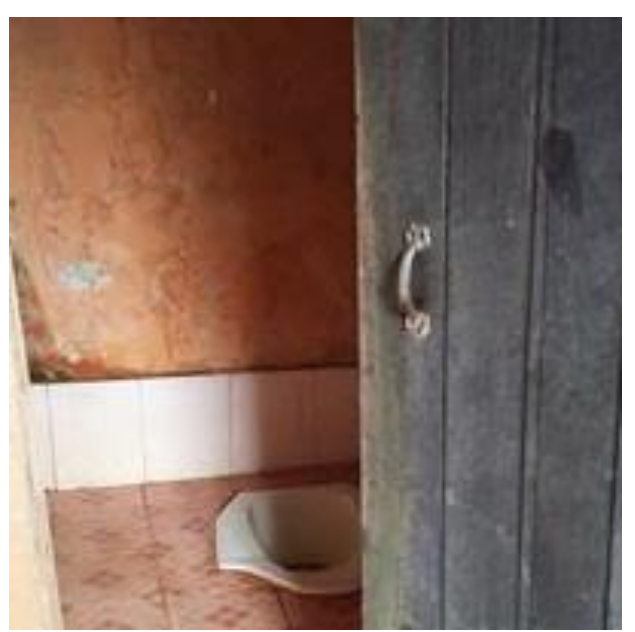
buang kedalam septic tank 


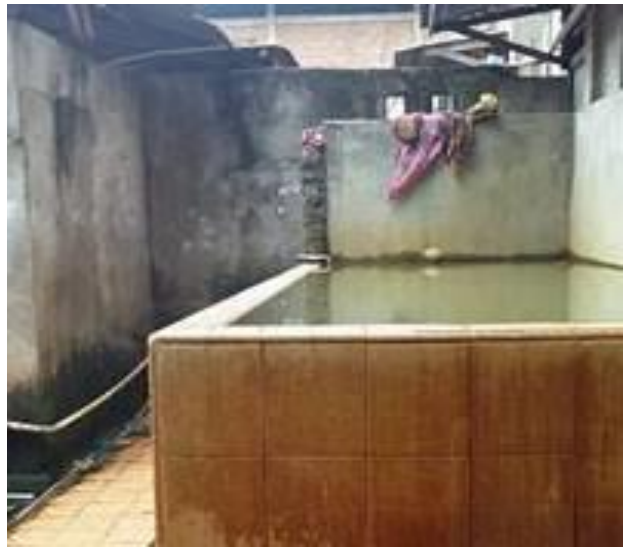

Sarana pembuangan sampah tidak ada, sampah hanya ditumpuk didalam wadah plastik pada halaman pesantren dan tidak bertutup
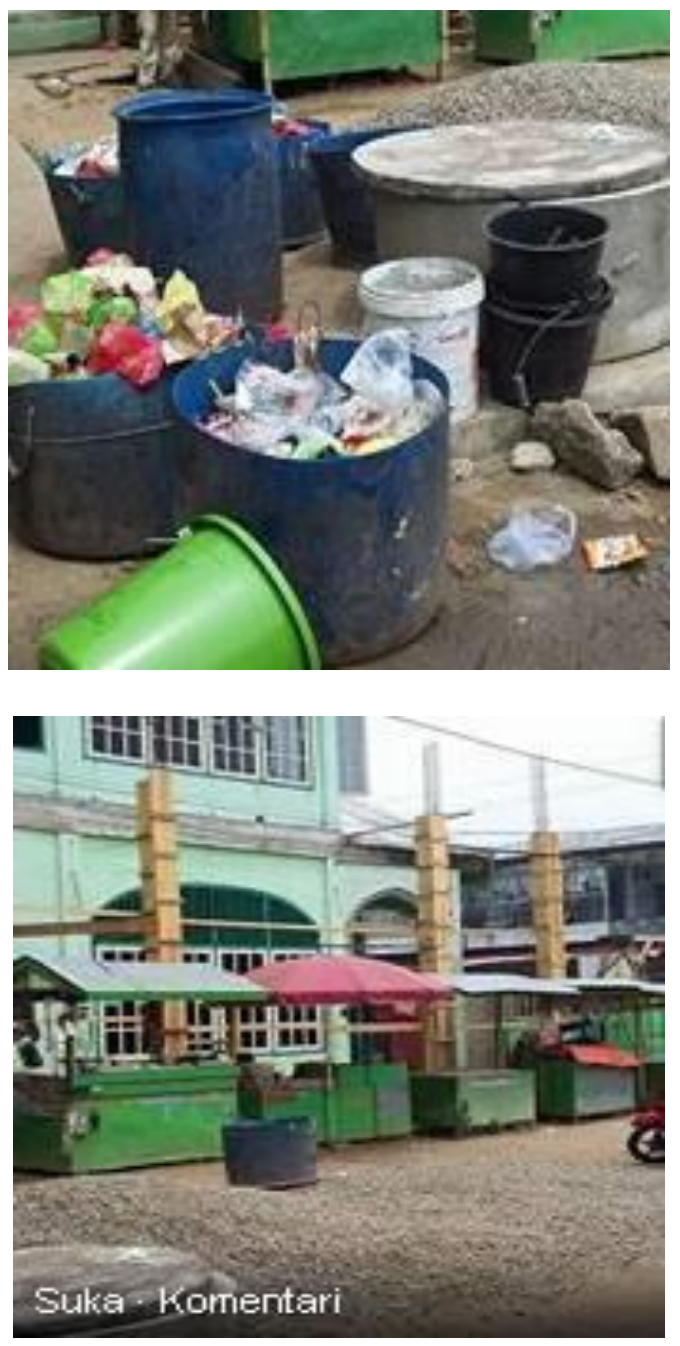

Air secara fisik kurang memenuhi syarat karena berwarna keruh, kamar mandi tidak bersih dan berbau, terdapat ventilasi namun tidak cukup untuk penerangan pada siang hari, lantai licin dan terdapat genangan air, tidak terdapat jentik nyamuk. WC tergabung dengan kamar mandi, dan tidak terdapat urinoir.
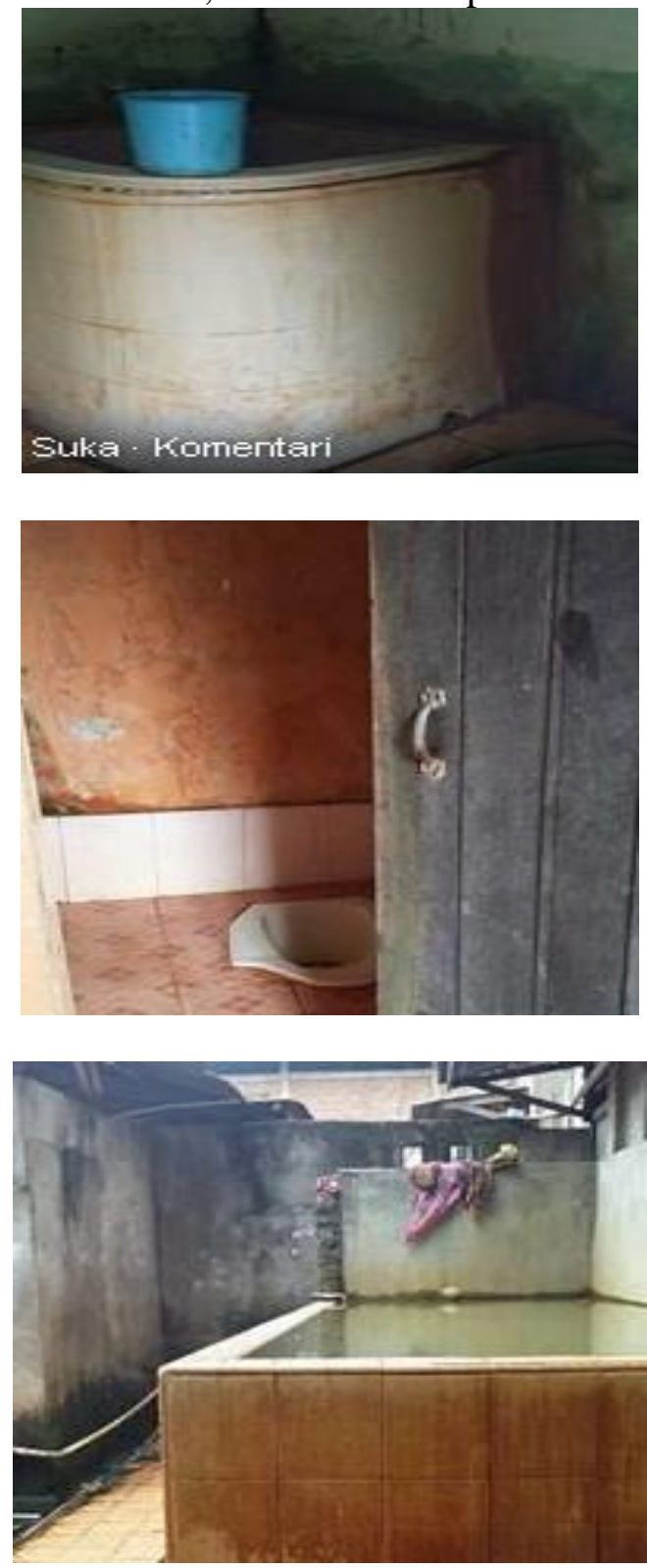

Tempat sampah terdapat di setiap ruang, kemudian dikumpulkan pada TPS yang terdapat dihalaman depan sekolah, tempat sampah tidak tertutup dan berserakan. 

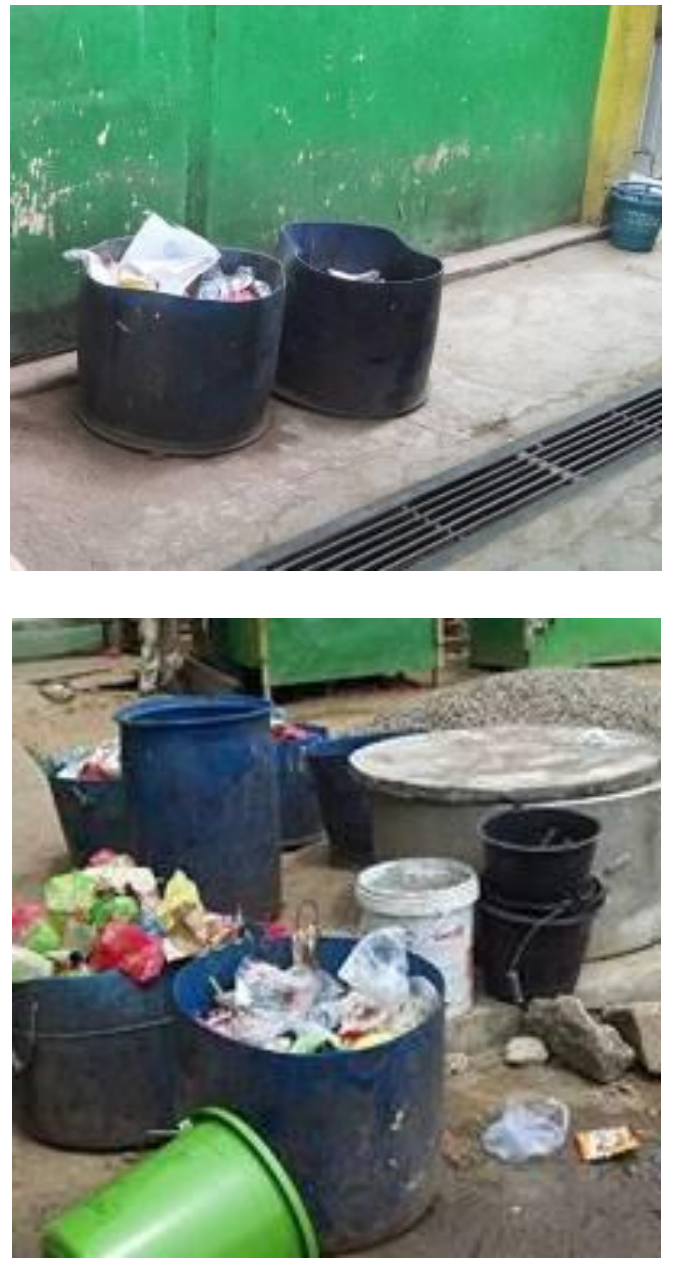

Sistem pembuangan air limbah langsung dibuang kedalam septic tank, namun air mandi para santri banyak tergenang di dalam saluran pembuangan tidak terdapat vektor pada tempat kegiatan belajar mengajar.

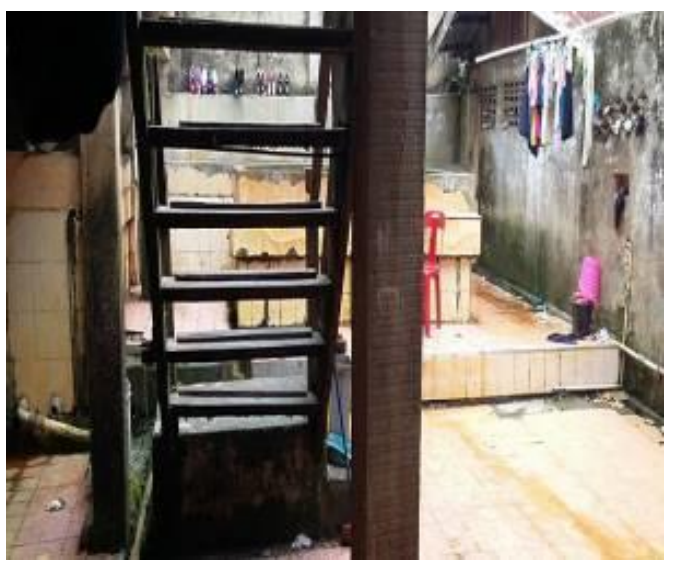

\section{Pengelolaan Makanan}

Tidak terdapat kantin dan tempat pengelolaan makanan di pondok pesantren As'ad, para santri memperoleh makanan dari Catering yang di selenggarkan oleh penduduk setempat, untuk jajanan, santri biasa membeli dari pada pedagang yang berjualan di halaman pondok pesantren

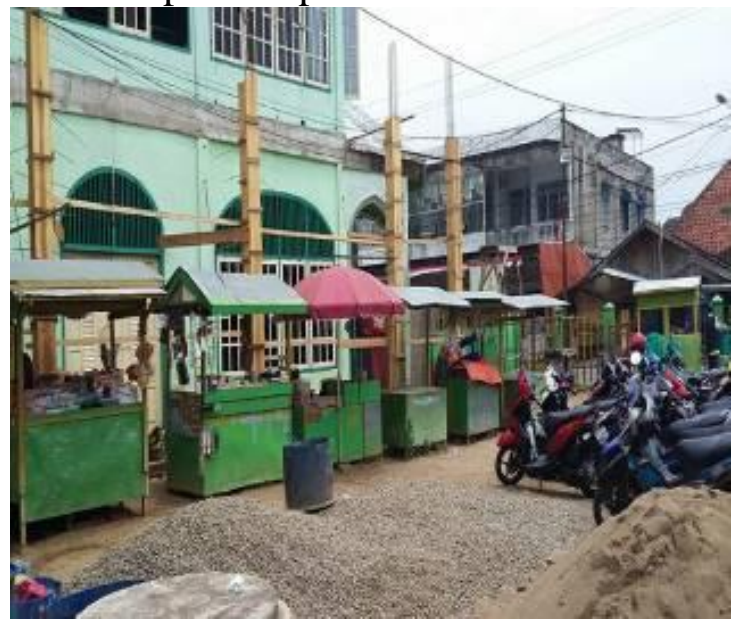

\section{Perilaku}

Penghuni pesantren tidak membuka jendela kamar tidur karena jendela hanya berupa ventilasi kaca dan udara, santri selalu membersihkan ruangan setiap hari sesuai jadwal piket

\section{Pengetahuan}

Dari 83 sampel yaitu santri lakilaki dan wanita diperoleh kesimpulan bahwa pengetahuan tentang sanitasi dasar para santri sangat kurang, santri tidak memiliki rasa ikut bertanggung jawab terhadap kebersihan dan kesehatan pondok pesantren.

Dari hasil wawancara dengan pengelola pondok pesantren, pengelola memiliki pengetahuan tentang sanitasi dasar namun dalam penerapannya terkendala perilaku santri dan biaya, biaya untuk memperbaiki konstruksi gedung dan kelengkapan sarana dan prasarana pondok pesantren. 


\section{SIMPULAN}

1. Penerapan Hygiene dan Sanitasi pada pondok Pesantren As,ad masih rendah

2. Pengetahuan santri tentang Hygiene dan Sanitasi pada Pondok pesantren rendah

Saran

1. Diperlukan pemahaman materi tentang sanitasi dasar kepada santri

2. Tenaga sanitasi diperlukan untuk memperbaiki kondisi sanitasi di pondok pesantren As'ad seberang kota Jambi

\section{DAFTAR PUSTAKA}

Azwar, Azrul, 1995.Pengantar Ilmu Kesehatan Lingkungan. Jakarta, Mutiara Sumber Widya: 58-78.

Menteri kesehatan Republik Indonesia, Keputusan 829/MENKES/SK/VII/1999

Tentang Persyaratan Kesehatan Perumahan.

Menteri Kesehatan Republik Indonesia, Peraturan Nomor: 416/MENKES/PER/IX/1990

Tentang Syarat-syarat Dan Pengawasan kualitas Air.

Menteri Kesehatan Republik Indonesia, Peraturan Nomor: 907/MENKES/SK/VII/2002

Tentang Syarat-syarat Dan Pengawasan Kualitas Air Minum.

Notoatmodjo, $\quad$ Soekidjo, 2012. Metodologi Penelitian Kesehatan. Jakarta, Rineka Cipta. Edisi Revisi Cetakan Kedua: 38.

Notoatmodjo, Soekidjo, 2012. Promosi Kesehatan dan Perilaku Kesehatan. Jakarta, Rineka Cipta. Edisi Pertama: 146-147.

Notoatmodjo, Soekidjo, 2011. Ilmu dan Seni Kesehatan Masyarakat. Jakarta, Rineka Cipta. Edisi Pertama: 183-197.
Notoatmodjo, Soekidjo, 2003. Perilaku dan Pendidikan Kesehatan. Jakarta, Rineka Cipta. Edisi Pertama: 131. Purwanto, D.S., 2011. Teknik Pengolahan Air Bersih. Surabaya, duatujuh. Edisi Pertama: 28-31.

Ricki, Mulia., 2005. Kesehatan Lingkungan. Yogyakarta, Graha Ilmu. Edisi Pertama:39-73.

Sutrisno, Totok, dan Eni Suciastuti, 2010.Teknologi Penyediaan Air Bersih. Jakarta, Rineka Cipta. Edisi Ketujuh: 12-32.

Suparlan, 2012. Pengantar Pengawasan Hygiene-Sanitasi Tempat-tempat Umum-Wisata dan Usaha-usaha Untuk Umum. Surabaya, Duatujuh: 12-51.

Sarudji, Didik, 2010. Kesehatan Lingkungan. Bandung, Karya Putra Darwati. Edisi Pertama: 57, 351362 